\title{
The amino acid sequence of a salivary peptide (F-A) with histamine-releasing property
}

\author{
Katsumi Sugiyama, Shinichi Miyoshi and Hiroaki Furuta \\ Department of Pharmacology (Chief: Prof. Hiroaki Furuta), Okayama University \\ Dental School, 2-5-1 Shikata-cho, Okaj'ama 700, Japan
}

[Accepted for publication: September 18, 1985]

\begin{abstract}
Key words: Human parotid saliva/histamine release / histidine-rich peptide / amino acid sequence
\end{abstract}

We have found that human parotid saliva contained the substances responsible for releasing histamine. They were basic peptides whose histidine contents were extremely high $^{1}$. Human parotid saliva has previously been shown to contain a group of histidinerich polypeptides (HRPs) ${ }^{2,3)}$. However, their function is unclear and the sequence of the individual HRPs have not been determined. In this report, we further purified one of the HRPs, F-A with histamine-releasing property and estimated its amino acid sequence.

\section{Materials and Methods}

A histamine-releasing peptide, F-A from human parotid saliva, was prepared as described previously ${ }^{11}$. Responses in vascular permeability were estimated by the passive skin test in rats ${ }^{4}$. Histamine releasing assay, using rat isolated mast cells was examined as reported previously ${ }^{5)}$. Amino acid analyses were performed on an automated amino acid analyzer (IRICA, model A-5500) after $24 \mathrm{~h}$ of hydrolysis in vacuo in $6 \mathrm{~N} \mathrm{HCl}$ at $120^{\circ} \mathrm{C}$. Sequence analysis was carried out by Edman degradation in an Applied Biosystems GasPhase model $470 \mathrm{~A}$ automatic sequencer. Phenylthiohydantoin derivatives of amino acids were identified by high performance liquid chromatography $\left(\right.$ HPLC) ${ }^{6}$.

\section{Results and Discussion}

Four fractions containing histamine-releasing peptides, F-A, F-B, F-C and F-D were obtained from Bio-Gel fraction by subsequent chromatography with DEAE-Sephacel and CM-cellulose. Polyacrylamide gel electrophoresis containing sodium dodecylsulfate and urea (SDS-PAGE) showed that F-A was homogenous and that its molecular weight was about 3000 as reported previous$\mathrm{ly}^{11}$. The F-A was further purified on a column $(0.8 \times 25 \mathrm{~cm})$ of Cosmosil $5 \mathrm{C}_{18}$ (Nakarai) by HPLC (Fig. 1). The result of the purification procedure was a single peak of peptide, the aliquote of which induced the histamine release from rat isolated mast cells. When the F-A was injected into rat skin intradermally, the vascular permeability was increased (Fig. 2). The response occurred with as little as $0.1 \mu \mathrm{g}$ of F-A, and increased as the concentration of F-A was raised. The injection of histamine $(1 \mu \mathrm{g})$ and a histamine releaser, compound $48 / 80$ $(0.5 \mu \mathrm{g})$, also induced the permeability response. These responses were completely abolished in all upon injection with $1 \mu \mathrm{g}$ of antihistamine, diphenhydramine hydrochloride (Fig. 2).

The amino acid composition of the purified F-A is shown in Table 1 . The peptide was sequenced from the $\mathrm{NH}_{2}$-terminus in one continuous run. The sequence of F-A was estimated as Asp-Ser-His-Ala-Lys-ArgHis-His-Gly-Tyr-Lys-Arg-Lys-Phe-His-GluLys-His-His-Ser-His-Arg-Gly-Tyr by Edman degradation.

Recently, the HRPs of human parotid saliva have been separated into 6 components by Baum et al. ${ }^{2)}$ and 14 by Mackay et al. ${ }^{3)}$ respectively, using cationic gel electrophore- 


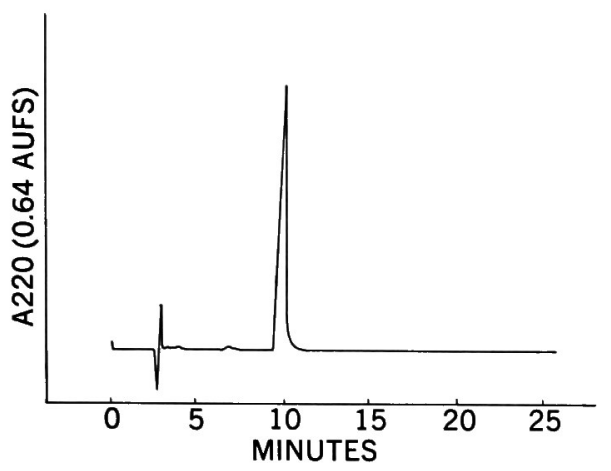

Fig. 1 High-performance liquid chromatogram of F-A. The mobile phase was the solvent of $7 \%$ n-propylalcohol in $0.1 \%$ trifluoroacetic acid. The flow rate was $1 \mathrm{ml}$ per min. The column used was Cosmosil $5 \mathrm{C}_{1 \mathrm{~s}}(0.8 \times 25 \mathrm{~cm})$.



Fig. 2 Vascular permeability responses of F$\mathrm{A}$ and its prevention by antihistamine. The black areas show the leakage of Evans blue. Site 1: saline, Sites 2, 3 and 4: F-A (0.1, 0.5 and $1 \mu \mathrm{g})$, Site 5: compound $48 / 80(0.5 \mu \mathrm{g})$, Site 6: histamine $(1 \mu \mathrm{g})$. Sites 7,8 , $9,10,11$ and 12: each of these sites tested with diphenhydramine $(1 \mu \mathrm{g})$.

sis. The F-A is considered as a peptide of these HRPs. The amino acid composition of the F-A was similar to HRP-5 reported by Baum $e t a l .^{2)}$ who estimated the molecular weight as 5600 . However, the molecular weight of F-A was 3000 as estimated by SDS-PAGE and its value was in good agreement with that (3015) calculated from the amino acid sequence. Therefore, the F-A is a new peptide of the HRPs in human parotid saliva and it stimulates histamine release
Table 1 Amino acid composition of F-A

\begin{tabular}{crc}
\hline Amino acid & Residues/100 residues \\
\hline Lys & 16.8 & $(4)$ \\
His & 28.6 & $(7)$ \\
Agr & 13.3 & $(3)$ \\
Asp & 4.6 & $(1)$ \\
Thr & - & \\
Ser & 7.2 & $(2)$ \\
Glu & 4.5 & $(1)$ \\
Pro & - & \\
Gly & 8.3 & $(2)$ \\
Ala & 4.1 & $(1)$ \\
Leu & 0.3 & \\
Tyr & 8.1 & $(2)$ \\
Phe & 4.2 & $(1)$ \\
\hline
\end{tabular}

Total residues 24

Numbers in parentheses are estimated after sequence analysis.

from mast cells both in vivo and in vitro.

\section{References}

1) Sugiyama, K., Suzuki, Y. and Furuta, H.: Isolation and characterization of histaminereleasing peptides from human parotid saliva. Life Sci. 37: 475-480, 1985.

2) Baum, B. J., Bird, J. L., Miller, D. B. and Longton, R. W.: Studies on histidine-rich polypeptides from human parotid saliva. Arch. Biochem. Biophys. 177: 427-436, 1976.

3) Mackay, B. J., Pollock, J. J., Iacono, V. J. and Baum, B. J.: Isolation of milligram quantities of a group of histidine-rich polypeptide from human parotid saliva. Infect. Immun. 44: 688-694, 1984.

4) Ishizawa, T. and Ishizaka, K.: Triggering of histamine release from rat mast cells by divalent antibodies against IgE-receptors. J. Immunol. 120: 800-805, 1978.

5) Sugiyama, K., Suzuki, Y. and Furuta, H.: Histamine-release induced by $7 \mathrm{~S}$ nerve-growth factor of mouse submandibular salivary grands. Arch. Oral Biol. 30: 93-95, 1985.

6) Ericsson, L. H., Wade, R. D., Gragnon, J., McDonald, R. M., Granberg, R. R. and Walsh, K. A.: In: Solid Phase Methods in Protein Sequence Analysis (Proviero, A. and Coletti-Previero, M. A., eds.), pp. 137-142, Elsevier/North Holland, Amsterdam, 1977. 